\title{
Penggunaan Internet Marketing Guna Peningkatan Daya Saing Pada Usaha Mikro Handycraft Di Kota Medan
}

\author{
Dedek Kurniawan Gultom, Delyana Rahmawany Pulungan, Salman Farisi \\ Fakultas Ekonomi Dan Bisnis, Universitas Muhammadiyah Sumatera Utara \\ dedekkurniawan@umsu.ac.id
}

\begin{abstract}
The implementation of the Community Partnership Program (PKM) aims to provide guidance and assistance to partners of micro handicraft entrepreneurs in implementing and implementing internet marketing as a means of business promotion to improve competitiveness and be able to manage business management that has an impact on expanding market aspects. This PKM program is held in 12 (twelve) months. The stages in implementing this PKM begin with Preparation, Direct Practice, Self-training, Implementation, Evaluation, and Development. The approach method used is the Learning Needs Based Method, Learning Goals and Objective, and Participant Center. The results achieved at this PKM are that Partners already have an Online Shop Website, scientific publications in community service journals, Publications on mass media / online, increased understanding, and business management skills and internet marketing, increased competitiveness, increased science, and technology in society and improved governance community value in the form of peace.
\end{abstract}

Keywords: Internet Marketing; Coaching; Handicraft; Business Management.

\begin{abstract}
Abstrak
Pelaksanaan Program Kemitraan Masyarakat (PKM) bertujuan untuk melakukan pembinaan dan pendampingan terhadap Mitra pelaku usaha mikro handycraft dalam menerapkan dan mengimplementasikan internet marketing sebagai sarana promosi usaha guna meningkatkan daya saing dan mampu mengelola manajemen usaha yang berdampak memperluas aspek pasar. Program PKM ini dilaksanakan dalam 12 (dua belas) bulan. Tahapan-tahapan dalam melaksanakan PKM ini dimulai dengan Persiapan, Praktek langsung, Self training, Implementation, Evaluasi dan Pengembangan. Metode pendekatan yang digunakan adalah Metode Learning Needs Based, Learning Goals and Objective, dan Participant Centre. Hasil yang dicapai pada PKM ini adalah Mitra sudah memiliki Website Toko Online, publikasi ilmiah di jurnal pengabdian masyarakat, Publikasi pada media masa/online, peningkatan pemahaman, dan keterampilan manajamen usaha dan internet marketing, peningkatan daya saing, peningkatan ipteks di masyarakat dan perbaikan tata nilai masyarakat berupa ketentraman.
\end{abstract}

Kata Kunci : Internet Marketing; Pembinaan; Handycraft; Manajemen usaha. 


\section{A. PENDAhuluan}

Kecamatan Medan Denai merupakan Kecamatan di Kota Medan yang mempunyai luas wilayah sekitar 9,91 km2 dengan ketinggian wilayah 25 meter di atas permukaan laut. Secara geografis, di sebelah Utara Kecamatan Medan Denai berbatasan langsung dengan Kecamatan Medan Tembung, sebelah selatan berbatasan dengan Kecamatan Medan Amplas, sebelah Barat berbatasan dengan Kecamatan Medan Area, sedangkan di sebelah Timur berbatasan dengan Kabupaten Deli Serdang Kelurahan Binjai merupakan kelurahan terluas di Kecamatan Medan Denai yaitu sekitar 4,14 KM2 atau sebesar 41,77 persen dari total luas Kecamatan Medan Denai, sedangkan kelurahan dengan wilayah terkecil yaitu Kelurahan Tegal Sari Mandala I dengan luas wilayah hanya $0,50 \mathrm{KM} 2$ atau sebesar 5,05 persen dari luas wilayah Kecamatan Medan Denai secara total (Badan Pusat Statistik, 2016).

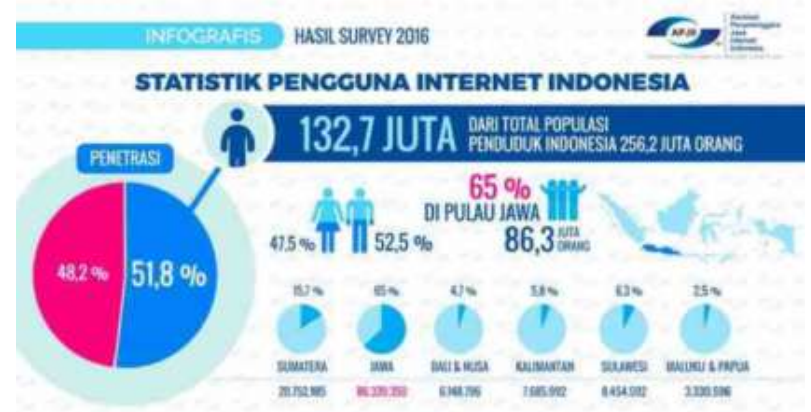

Gambar 1. Statistik Pengguna Internet Indonesia 2016, (BPS dan APJII, 2016)

Gambar 1 memperlihatkan jumlah pengguna Internet di Indonesia tahun 2016 adalah 132,7 juta user atau sekitar 51,5\% dari total jumlah penduduk Indonesia sebesar 256,2 juta. Pengguna internet terbanyak ada di pulau Jawa dengan total pengguna 86.339 .350 user atau sekitar $65 \%$ dari total penggunan Internet. Jika dibandingkan penggunaan Internet
Indonesia pada tahun 2014 sebesar 88,1 juta user, maka terjadi kenaikkan sebesar 44,6 juta dalam waktu 2 tahun (2014 - 2016). Tentu data / fakta ini menggembirakan, terutama bagi para pengusaha atau pemilik toko online. Pada Gambar 2.2, Pengguna internet berdasarkan usia, pengguna terbanyak adalah usia 35-44 tahun sebesar $29,2 \%$. Sedangkan pengguna paling sedikit adalah usia 55 tahun ke atas hanya sebesar 10\%. Dalam menghadapi mekanisme pasar yang makin terbuka dan kompetitif, penguasaan pasar merupakan prasyarat untuk meningkatkan daya saing UKM. Agar dapat menguasai pasar, maka UKM perlu mendapatkan informasi dengan mudah dan cepat, baik informasi mengenai pasar produksi maupun pasar faktor produksi. Informasi tentang pasar produksi sangat diperlukan untuk memperluas jaringan pemasaran produk yang dihasilkan oleh UKM (Julisar dan Miranda, 2013). Lebih lanjut Julisar dan Miranda, (2013) mengatakan bahwa Pemanfaatan internet memungkinkan Usaha Kecil dan Menengah melakukan pemasaran dengan tujuan pasar global, sehingga peluang menembus ekspor sangat mungkin. Julisar dan Miranda, (2013) memberikan pendapat mengenai hal positif yang dapat diperoleh dengan memanfaatkan jaringan internet dalam mengembangkan usaha adalah (1) dapat mempertinggi promosi produk dan layanan melalui kontak langsung, kaya informasi, dan interaktif dengan pelanggan (2) menciptakan satu saluran distribusi bagi produk yang ada (3) biaya pengiriman informasi ke pelanggan lebih hemat jika dibandingkan dengan paket atau jasa pos (4) waktu yang dibutuhkan untuk menerima atau mengirim informasi sangat singkat, hanya dalam hitungan menit atau bahkan detik.

Menurut Supriyati dan Iqbal, (2013) internet dapat menjangkau semua wilayah, potensial dan cepat untuk menyampaikan 
berbagai informasi secara universal, berkualitas, dan hampir tidak memerlukan cost. Selain itu, internet juga memiliki beberapa daya tarik dan keunggulan bagi para konsumen maupun organisasi, misalnya dalam kenyamanan, akses 24 jam sehari, efisiensi, alternatif ruang maupun pilihan yang relatif "tak terbatas"e, personalisasi, sumber informasi potensial, dan lain-lain. Pengaruh globalisasi yang tak terelakkan mengakibtakan setiap organisasi bisnis termasuk juga UMKM harus berhadapan dengan kompetisi yang semakin kompleks. dilakukan sebelum implementasi. UMKM memiliki ciri yang khusus yaitu resiko kegagagalan bisnis yang besar, anggaran yang terbatas, dan pengambilan keputusan cenderung terpusat pada pemilik (Supriyati dan Iqbal, 2013).

$$
\text { Pengguna internet terbanyak }
$$

berprofesi sebagai Pekerja Wiraswasta sebesar 82,2 juta atau 62\%. Urutan pengguna internet berikutnya berprofesi sebagai Ibu Rumah Tangga (IRT) sebesar 22 juta atau $16,6 \%$, sedangkan pada gambar 1.4, terlihat bahwa konten yang paling sering dijunjungi, pengguna internet paling sering mengunjungi web onlineshop sebesar 82,2 juta atau $62 \%$, dan konten social media yang paling banyak dikujungi adalah Facebook sebesar 71,6 juta pengguna atau $54 \%$ dan urutan kedua adalah Instagram sebesar 19,9 juta pengguna atau $15 \%$. (Statistik Pengguna Internet Indonesia 2016, Badan Pusat Statistik dan APJII, 2016)

Nasution, dkk, (2017); Sukarsih, dkk, (2016) menyatakan bahwa peserta UMKM setelah diberikan pelatihan dan pendampingan internet marketing, pengetahuan dan kemampuan pengrajin UKM tentang pemanfaatan teknologi internet sebagai media pemasaran online meningkat. Perkembangan UMKM yang ada saat ini harus diimbangi dengan adanya daya saing dari setiap UMKM, sehingga UMKM dapat bertahan dan berhasil menhadapi tantangan dan persaingan yang ada. Kemudian Mujiyana, dkk, (2012) mengatakan bahwa salah satu daya saing yang harus dimiliki oleh UMKM adalah penguasaan teknologi informasi, kegiatan promosi atas suatu produk akan lebih optimal hasilnya apabila program periklanan yang dilakukan pada media internet juga diimbangi dengan tingginya pemasaran melalui e-mail, maka pemprosesan informasi oleh konsumen akan semakin baik. Pemakaian Teknologi Informasi (IT) dalam memasarkan produk UKM telah berhasil dikembangkan oleh sejumlah Negara seperti Cina, Jepang, dan India. Bahkan Konfederasi Industri India atau Confedration of Indian Industry (CII) merilis hasil survey yang memperlihatkan bahwa peranan Teknologi Informasi (IT) telah mengubah peruntungan sigmen UKM di India. Menurut hasil survey tersebut penggunaan IT di kalangan UKM telah menghasilkan peningkatan pendapatan yang signifikan, yakni $78 \%$ dari responden mengindekasikan peningkatan pendapatan akibat penggunaan IT (Jauhari, 2010).

Salah satu keuntungan dari ecommerce yang dapat dirasakan oleh pelaku UKM atau pun konsumen UKM itu sendiri. Secara umum, keuntungan e-commerce sebagai berikut: 1) Kecepatan. Web Internet dan world wide memberikan bisnis peluang untuk bertukar pesan atau transaksi yang lengkap hampir seketika. Bahkan dengan koneksi lambat, melakukan bisnis secara elektronik jauh lebih cepat daripada cara tradisional. 2). Hemat Biaya. Dengan menggunakan internet, biaya pemasaran, distribusi, telepon, pos dan percetakan, dan lainnya, dapat dikurangi. 3). Tidak ada batasan wilayah. Ini berarti pelaku UKM dapat melakukan bisnis di seluruh dunia 
dengan mudah karena internet menghubungkan semua orang di dunia maya, informasi yang dikirim dengan kecepatan suara atau kecepatan cahaya, tergantung pada koneksi. 4). Mudah mencari jaringan. Satu keuntungan dari Internet adalah yang memungkinkan orang untuk dengan mudah bertemu, mengumpulkan data/informasi dan tetap berhubungan dengan orang lain dengan biaya yang sangat rendah (Kautsarina, 2013).

Hasil observasi yang diperoleh salah satu usaha mikro yang mempunyai potensi untuk dapat berkembang di Kota Medan adalah industry kreatif handicraft, pemiliah ini berdasarkan atas survey potensi pasar dan belum berkembangnya usaha mikro kerajinan (handicraft). Potensi ini perlu dikembangkan sejalan dengan perkembangan Kota Medan sebagai salah satu destinasi wisata. Berdasarkan survey dan observasi maka perlu pengembanga pemasaran industry inacraft yang selama ini belum menjadi produk andalan kota Medan. Pentingya promosi internet juga didukung oleh penelitian Kautsarina, (2013) bahwa pentingnya internet dalam pemasaran merupakan unsur yang tidak bisa diragukan lagi. Paul Smith memasukkan internet sebagai bagian dari aktivitas pemasaran/komunikasi.

Pemilihan kepada kedua Mitra karena produk kedua mitra belum dikenal di masayarakat maka itu perlu memperkenalkan produk kedua Mitra ini kepada masyarakat, disamping itu juga Produk yang dihasilkan Mitra ini belum mampu mengoptimalkan pemasaran melalui internet, sehingga omzet penjualan pun tidak meningkat, bahkan cendrung tidak memiliki orderan, itulah perlunya promosi melalui internet marketing agar produk yang dihasilkan oleh Mitra mampu bersaing. Produk yang dihasilkan Mitra berupa kerajainan tangan berbahan dasar bubuk teh bekas yang diolah oleh mitra menjadi celengan, bingkai, dan lain-lain, tas yang terbuat dari goni sebagai souvenir, handicraft perlu dikembangkan agar generasi muda lebih kreativ dan inovatif. Hasil dari observasi dan wawancara yang dilakukan oleh pelaku usaha handycraf ada beberapa kendala dan permasalahan yang dihadapi mitra Permasalahan utama yang dihadapi adalah mengenai manajemen usaha maupun pemasaran adalah 1) Ketidakmampuan mitra dalam melakukan promosi melalui internet marketing, karena untuk melakukan promosi internet marketing perlu keahlian khusus, 2) untuk belajar internet marketing mereka tidak mempunyai modal yang cukup karena mahalnya untuk belajar menguasai internet marketing. Penguasaan internet marketing di zaman globalisasi ini sangat penting untuk melakukan penetrasi pasar agar omzet produk dasri usaha yang mereka hasilkan bisa meningkat.1) Keterbatasan pengetahuan dalam pemanfaatan akses dan penguasaan teknologi, khususnya teknologi internet marketing, 3) Metode pemasaran yang yang digunakan masih konvensional dari mulut ke mulut dan hanya berdsarkan pesanan dan atau hanya sebatas kepemilikan modal saja. 4) Belum menjangkau pasar yang luas. 5) Belum menggunakan teknologi internet secara maksimal, 6) belum menjalin kerjasama dengan instansi ataupun lembaga lain untuk melakukan pemasaran 7) Keterbatasan pengetahuan mitra dalam pengelolaan manajemen usaha yang prosfesional, seperti pengelolaan keuangan, administrasi, menentukan harga pokok produksi, 8) Tidak adanya pembukuan usaha sehingga cenderung tidak bisa membedakan antara keuangan pribadi dan usaha, akibatnya, Mitra sulit menghitung pengeluaran dan pendapatan, sehingga sering terjadi miskalkulasi dan inefisiensi. 10) Sementara dalam pemasaran, Mitra 
belum menerapkan kaidah-kaidah pemasaran yang benar, secara sederhana, misalnya aspek pemasaran mencakup aspek produk, biaya distribusi dan promosi, 11) Kurang kesadaran dan motivasi dari pengusaha sendiri untuk mengembangkan usaha lebih professional, 12) Mekanisme dan birokrasi yang berbelit dalam proses perijinan sehingga mitra malas untuk melakukan perizinan, dan terkesan takut dikenakan pajak oleh pemerintah. 13) Belum ada kebijakan baik dari Pemerintah Daerah maupun setempat yang dapat mendukung produk usaha ini, sehingga dirasakan oleh pelaku usaha terkendala dalam pemasaran produk yang setidaknya dapat memiliki nilai jual lebih tinggi apabila bisa dipasarkan ke luar daerah bahkan bisa sampai ke luar negeri. 14) Merek dari produk yang dihasilkan oleh pengrajin tidak terdaftar, hal ini disebabkan karena biaya untuk mendaftarkan merek dari hasil produk sangat mahal, Merek yang mereka buat adalah merk sendiri atau tidak bermerk. Disamping permasalahan tersebut maka ditemukan juga permasalahan lain kedua Mitra diantara nya menganai manajemen usaha dan manajemen pemasaran 1). Mitra tidak mengetahui strageti pemasaran yang baik, 2) masih belum ada pemisahan antara keuangan pribadi dan keuangan usaha, sehingga Mitra mengalami kesulitan dalam menghitung keuntungan yang mereka peroleh 3) Belum mampunya Mitra memanfaatkan teknologi informasi untuk mendukung strategi pemasaran dan produksi secara detail. Untuk itu Mitra mengatasi persoalan-persoalan Mitra dalam menghadapi persaingan dan meningkatkan imzet pelaksaaan PKM ini dianggap perlu sebagai salah satu solusi dalam membantu Mitra meningkatkan omzet melalui promosi internet dan sebagai wujud sudah saatnya usaha mikro go online.

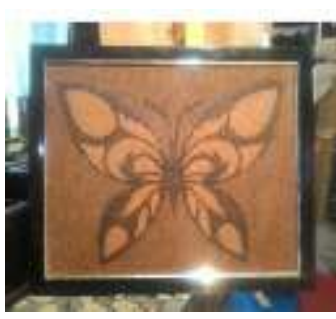

a.

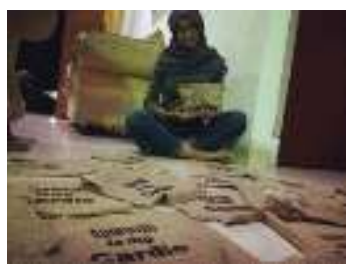

c.

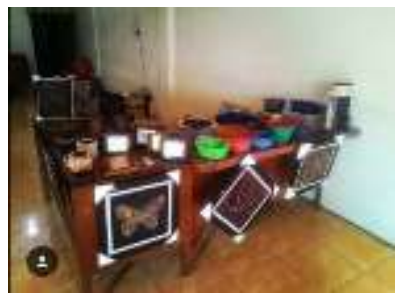

b.

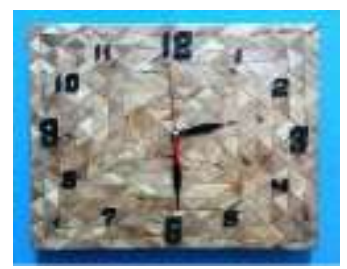

d.
Gambar 2: a. Product handycraft untuk hiasan dinding, b) Meja Produksi Handycraft yang akan dihasilkan, c) Proses pembuatan tas handycraft yang dihasilkan mitra d). Handycraft jam dinding siap untuk dijual.

\section{B. PELAKSAAAN DAN METODE}

Pelaksana Program Kemitraan Masyarakat (PKM) sesuai dengan rencana, yang meliputi tahapan (1) Persiapan. Suatu Kondisi yang memberi kemudahan kepada Mitra untuk memunculkan kreativitasnya. Ini diperoleh dengan, mendengar keluhan mitra, menampung ide-ide kreatif mitra, (2) Praktek langsung: Metode ini dilakukan dengan cara, mengajarkan Mitra cara menggunakan Intenet Marketing, dan mengetahui bagaimana proses manajemen usaha yang baik, yang dilatih oleh orangorang yang professional dibidangnya. (3). Self training: Metode ini dilakukan untuk Mitra, agar mitra mengerjakan tugas-tugas yang diberikan oleh instruktur internet marketing, sebagai test case. (4) Implementation. Mulai mentransformasi ide menjadi kenyataan dan digunakan. Disini mitra mulai mengimplementasikan dan membidik target pasar mana yang akan dituju. (5) Evaluasi. Langkah ini merupakan kegiatan untuk mengetahui "nilai lebih" dari 
hasil kreativitas yang dilakukan. Mengevaluasi dari hasil impelementasi yang dilakukan oleh Mitra, apakah masih ada yang perlu diperbaiki dan bagamaimana caranya? (6) Pengembangan. Semua pertanyaan yang dikemukakan pada langkah evaluasi merupakan bahan untuk pengembangan.

Pelaksanaan PKM diikuti oleh Dua Mitra, Second Art dan Izal Art (Medan handycraft, peserta merupakan pemilik usaha handycraft yang perlu mendapat perhatian dari perguruan tinggi, dengan motivasi mereka untuk terus mempertahankan eksistensi handycraft di Kota Medan, agar menjadi produk unggulan di Kota Medan. Pelaksanaan dimulai bulan Februari sampai dengan September 2018, kemudian pelatihan Internet Marketing dengan menggunakan Website Toko Online, peserta di latih pada tanggal 10 September 2018 di Jalan Ringroad Medan, pelatihan ini juga diikuti 8 peserta terdiri dari 4 orang sebagai pemilik usaha mikro handycraft dan 4 orang mahasiswa Fakultas Ekonomi dan Bisnis, dimana mahasiswa juga diberikan waktu untuk melatih para peserta dengan memberikan pengetahuan tentang manajemen pemasaran, sebagai wujud aplikasi mata kuliah yang telah mereka peroleh selama perkuliahan.

Kemudian metode pelaksanaan PKM dilakukan dengan cara mengajarkan Mitra cara menggunakan Intenet Marketing (praktek langsung), serta tanya jawab selama kegiatan PKM berlangsung, dan evaluasi ini bertujuan untuk mengevaluasi tingkat keberhasilan program, dan sejauh mana mitra memahami apa yang dipelajari dalam internet marketing.

Sedangkan materi dalam kegiatan ini adalah penggunaan strategi internet marketing, manajemen usaha yang bertujuan untuk dan memberikan pengetahuan bagaimana mengelola usaha dengan baik, strategi pemasaran, yang bertujuan untuk memberikan pemahaman kepada mitra tentag strategi pemasaran yang baik, serta motivasi, agar mitra terus termotivasi untuk mempertahankan eksistensi usaha.

Pendekatan yang dilakukan kepada mitra selama Program Kemitraan Masyarakat ini dengan cara (1) Metode Kebutuhan Belajar (Learning Needs Based). Sumber informasi tentang kebutuhan belajar peserta atau calon peserta. Pentingnya metode ini akan didasarkan kepada atas asumsi bahwa peserta akan belajar secara ekfektif bila semua komponen pembelajaran dapat membantu mereka untuk memenuhi kebutuhannya. (2) Berorientasi pada tujuan kegiatan belajar (Learning Goals and Objective) . Tujuan belajar disusun bersama sumber belajar bersama peserta, potensi yang dimiliki serta sumber-sumber yang tersedia di lingkungan kehidupan mereka serta kemungkinan hambatan-hambatan yang muncul dalam kegiatan pembelajaran. (3) Berpusat pada peserta (Participant Centre). Peserta diikutsertakan dan harus berperan aktif dalam kegaitan perencanaan, pelaksanaan, dan evaluasi, mereka tidak hanya menjawab pertanyaan-pertanyaan yang berhubungan dengan kebutuhan belajar atau evaluasi belajar, akan tetapi beperan dalam merumuskan alat-alat instrument yang digunakan untuk kegiatan pembelajaran, dan ikut mengembangkan bahan pembelajaran.

\section{HASIL DAN PEMBAHASAN}

Tim PKM membantu mitra untuk menedesain website atau Toko Online yang bisa digunakan untuk meningkatkan daya saing penjualan Handycarft, sehingg hasil dan luaran yang dicapai setelah pelaksanaan PKM bagi mitra adalah: 1. Mempunyai ebsite untuk promosi dan penjualan, (2) Meningkatnya keterampilan dalam 
melakukan penjulan melalui internet (3. Peningkatan Motivasi dalam usaha mandiri. (4) Bagi Tim PKM menghasilkan publikasi jurnal atau prosiding Pengabdian Masyarakat. Tim PKM membantu melakukan pendampingan dan pelatihan kepada Mitra, maka hasil yang dicapai pada pelaksanaan PKM ini adalah dengan adanya Website Jualan Online Mitra dapat dilihat pada Gambar 4 berikut :

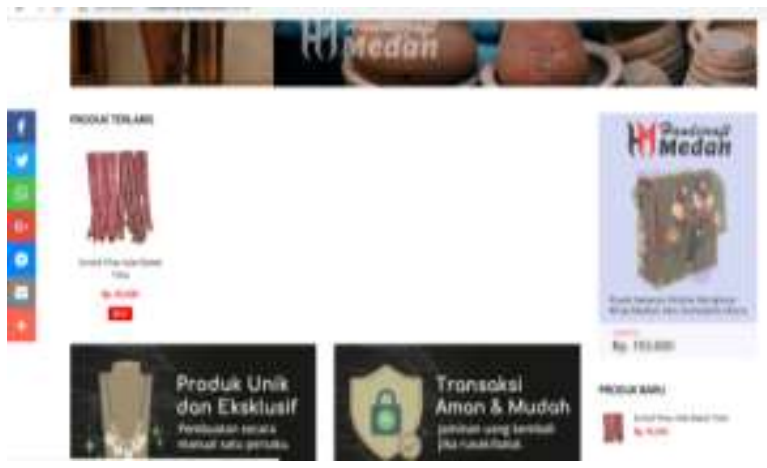

Gambar 4. Tampila Website Toko Online Mitra Izal art (Medan Handycraft).

Tim PKM membantu mitra untuk menedesain website atau Toko Online yang bisa digunakan untuk meningkatkan daya saing penjualan Handycarft, sehingg hasil dan luaran yang dicapai setelah pelaksanaan PKM bagi mitra adalah: (1). Mempunyai website untuk promosi dan penjualan, (2) Meningkatnya keterampilan dalam melakukan penjulan melalui internet, (3)Peningkatan Motivasi dalam usaha mandiri. (4) Bagi Tim PKM menghasilkan publikasi jurnal atau prosiding Pengabdian Masyarakat. Tim PKM membantu melakukan pendampingan dan pelatihan kepada Mitra, maka hasil yang dicapai pada pelaksanaan PKM ini adalah dengan adanya Website Jualan Online Mitra dapat dilihat pada gambar 3 berikut :
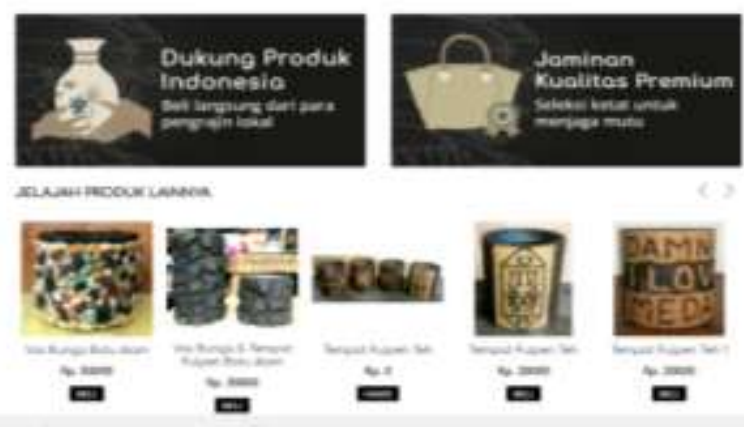

Gambar 3: Tampilan Website Mitra Secondart

Selain pelatihan Internet Marketing Mitra juga diajarkan bagaiamana memanajemen usaha dan diberikan pelatihan memasarkan produk melalui Internet Marketing sehingga kesulitan-kesulitan mitra selama ini dapat teratasi oleh Internet Marketing.

Dengan adanya website hasil dari Program Kemitraan Masyarakat dapat meningkatkan daya saing UMKM pada bidang Handycraft disamping itu juga dapat dengan cepat melakukan promosi keberbagai pelosok dunia, dan pangsa pasar luar negeri juga dapat di capai dengan adanya website toko online Handycraft.

Toko online ini disesain sedemikian rupa untuk memudahkan konsumen dalam melakukan pembelian, dan disesain juga lebih sederhana agar Mitra mudah untuk menginput produk ke dalam Wesbsite.

Dengan adanya Website hasil dari Program Kemitraan Masyarakat dapat meningkatkan daya saing UMKM pada bidang Handycraft disamping itu juga dapat dengan cepat melakukan promosi keberbagai pelosok dunia, dan pangsa pasar luar negeri juga dapat di capai dengan adanya website Toko online Handycraft.

Selain pelatihan Internet Marketing Mitra juga diajarkan bagaiamana memanajemen usaha dan diberikan pelatihan memasarkan produk melalui Internet Marketing sehingga kesulitan-kesulitan 
mitra selama ini dapat teratasi oleh Internet Marketing.

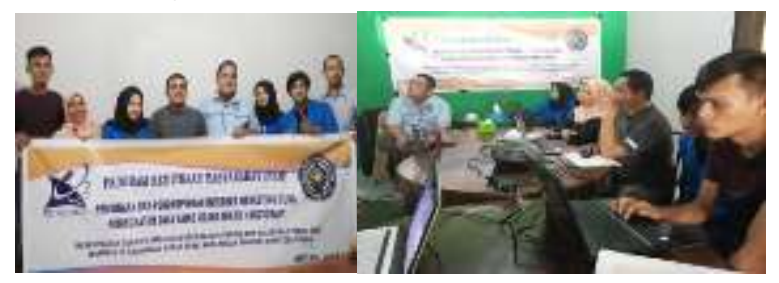

Gambar 5. Aktivitas Kegiatan dan pendampingan Mitra (kanan), foto bersama mitra dan tim PKM usai kegiatan (kiri).

\section{PENUTUP}

\section{Simpulan}

Pentingnya pendekatan yang dilakukan oleh Perguruan Tinggi untuk menjawab permasalahan pada masyarakat, agar masyarakat dapat bertumbuh dan berkembang dalam menjalankan usahanya. Program Kemitraan Masyarakat yang dilaksanakan oleh Universitas Muhammadiyah Sumatera Utara sangat membantu masalah Mitra, dari tidak ada website untuk sarana promosi dan hanya mengandalkan jualan melalui konvensional, saat ini Mitra sudah memiliki Website yang bisa digunakan sebagai sarana promosi dan juga jualan online. Kegiatan Program Kemitraan Masyarakat sangat memiliki dampak perubahan pada Mitra menjadi lebih bersemangat dalam berusaha dan usaha yang mereka jalankan seperti sudah profesional.

\section{Saran}

Akhir pelaksanaan kegiatan pengabdian masyarakat ini tentunya memiliki keterbatasan serta keunggulan yang diperoleh dari pengabdian masyarakat ini, hal yang dapat kami sarankan dari kegiatan ini adalah, usaha-usaha mikro handycraft harus mendapatkan perhatian dari perguruan tinggi, terutama dalam pembinaan marketing online, dengan adanya marketing online maka mitra akan lebih mudah untuk mempromisikan produk- produk yang akan dijual. Facebook, twiter, Whatsap dan media social lainnya tidaklah cukup untuk melakukan promosi, maka Mitra harus memiliki website Toko online yang elegan agar dapat meningkatkan reputasi dan kepercayaan masayrakat terhadap usaha yang dijalani oleh Mitra. Terlebih lagi Perguruan Tinggi harus aktif melihat kondisi UMKM Handycraft agar mampu bersaing pada pasar Global, Website ini tidak hanya berhenti sampai disini, dan akan terus dikembangkan pada programprogram kemitraan masyarakat baik yang dilaksanakan oleh Kemenristek Dikti, Internal kampus, dan lainnya. Kita semua berharap UMKM Indonesia bisa jaya dan maju asalkan kita Bersama-sama membantu permasalahan yang ada di masyarakat.

\section{Ucapan Terima Kasih}

Ucapan terimakasih kepada Kementrian Riset dan Teknologi (Kemenristekdikti) Republik Indonesia yang telah memberikan dukungan dalam pelaksanaan Program Kemitraan Masyarakat dan kepada jajaran pimpinan Universitas Muhamamdiyah Sumatera Utara yang terus memberikan dukungan motivasi kepada tim PKM untuk melaksanakan Tri Dharma Perguruan Tinggi.

\section{E. DAFTAR PUSTAKA}

Badan Pusat Statistik. (2016). Statistik Daerah Kecamatan Medan Denai. Medan: BPS Kota Medan.

Jauhari, J. (2010). Upaya Pengembangan Usaha Kecil Dan Menengah (UKM) Dengan Memanfaatkan E-Commerce. Jurnal Sistem Informasi (JSI), 2(1), 159-168. 
Julisar, \& Miranda, E. (2013). Pemakaian ECommerce Untuk Usaha Kecil Dan Menengah Guna Meningkatkan Daya Saing. ComTech, 4(2), 638-645.

Kautsarina. (2013). Pemasaran Elektronik Melalui Aplikasi Jejaring Sosial (Survei Pelaku UKM di Provinsi Jambi dan Bengkulu). Jurnal Studi Komunikasi Dan Media, 17(2), 135147.

Mujiyana, Sularto, L., \& Mukhyi, M. A. (2012). Pengaruh Penerapan Periklanan Di Internet Dan Pemasaran Melalui EMail Produk UMKM Di Wilayah Depok.J@ti Undip, 7(3), 161-168.

Nasution, M. I., Prayogi, M. A., \& Nasution, S. M. A. (2017). Pembinaan Pengelolaan Manajemen Usaha Dan EMarketing Pada Pelaku Usaha Industri Mikro Pengrajin Sepatu Di Kecamatan Medan Denai. Jurnal Pengabdian Kepada Maryarakat (JPKM), 23(2), 292-299.

Sukarsih, I., Kurniati, E., Gunawan, G., \& Respitawulan. (2016). Perluasan Jangkauan Pasar Pelaku Ukm Sepatu Cibaduyut Melalui Pelatihan Dan Pendampingan Internet Marketing. Ethos (Jurnal Penelitian Dan Pengabdian Masyarakat), 4(1), 1-6.

Supriyati, E., \& Iqbal, M. (2013). Faktor Adopsi Internet Marketing Untuk Usaha Mikro Dan Usaha Kecil Menengah (UMKM) Di Kabupaten Kudus Dengan SEM (Structural Equation Model) Dan Framework Cobit 4. Jurnal Simetris, 3(1), 1-6. 